\title{
The Influence of Selfhelp Groups in Enhancing Social Integration and Decision Making among the Widows in Kenya
}

\author{
Jeniffer Birech \\ University of Nairobi \\ Department of Sociology and Social Work \\ Jamin Masinde \\ Moi University \\ Department of Sociology and Psychology
}

\begin{abstract}
The challenges of widowhood continues to be alarming worldwide with the number of widows increasing globally. Widows comprise a significant proportion of $7 \%$ to $16 \%$ of of all adult women populations. The ratio of widows to that of widowers is as high as 4:1. While the loss of a spouse precipitates disruption of the family, its consequences are not the same for men and women. The widows face social and economic challenges such as loss of income, inheritance of property, participation in social activities and decision making in the family. This paper examines the social challenges with restriction itself to social integration and decision making pointing out the benefits of group participation.The paper is based on the findings of a study carried out among the widows in Kenya.Grounded on social exchange theory by Peter Blau, Social Network theory and the theory of Redefinition of a situation by William Thomas, the study found out that there are more young widows below fourty five years $(56 \%)$ than older ones. Most (77\%) of the widows however belonged and participated in self help groups which had been beneficial, At least $23 \%$ did not belong to any group missing out on opportunities. Those in self help groups felt more integrated into the community through participating in projects such as planting trees, attending trainings organized by the groups, visiting one another and selling and buying on behalf of their groups.Their self esteem improved and they could make decisions on behalf of the family. However, it was observed that leadership of the groups is wanting thus needful to equip them with leadership skills. The paper recommends training opportunities by the government, religious organizations and other stakeholders to create awareness on the social integration and encourage all widows to participate.
\end{abstract}

Key Words: Selfhelf groups, Widows, Social integration, Decision making, Kenya.

\section{INTRODUCTION}

Widowhood is a condition where a person has lost a spouse either a husband or wife. A Widow is one whose husband has died and has not remarried.Globally,various studies continue to indicate an increasing number of widowed persons. According to Global Widows Report 2015, there are approximately 258 million widows around the world , a 9\% global increase from 237 million in 2010[3].Widows comprise a significant proportion of all women ranging from $7 \%$ to $16 \%$ of all adult women populations [1, 2]. According to United States Cencus Bureau (2000) there are approximately 700,000 new widows every year and are expected to be widows for an average of 14 years before they die. In India alone there are 46 million widows being the highest number of widows in the world followed by China with approximately 44 million [3]. In Africa armed conflict and HIV/AIDS have brought widowhood prematurely to millions of women. A wave of genocide created 500,000 widows in Rwanda, especially the 1994 genocide. An estimated $60 \%$ of adult women were widowed by wars inAngola and Mozambique [4]. 
In Kenya, according to the Global Widows Report 2015 there are approximately 1.4 million widows. According to the Census reports of 1989, 1999 and 2009, female headed households were $34 \%, 35 \%$ and $37 \%$ respectively of which widows were estimated to be $20 \%$. In the rural areas, female headed households stand at 36\% while in the urban areas they are $29 \%$ [KDHS 2008-2009]. Part of the increase has been attributed to HIV/AIDS among others [5-8]. According to Mathews [1] and Martha [2] the proportion of widowed women over 60 years is $40 \%$ in developed countries as compared to $50 \%$ in developing countries; particularly in Africa and Asia. Furthermore, whereas the proportion of all widows below 60 years of age is $15.8 \%$ in the developed countries, it ranges from $34.4 \%$ to $43.6 \%$ in the developing countries. More importantly, most of the studies have pointed out that widowhood is experienced primarily by elderly women in developed countries and younger women in developing countries, many of them still rearing young children. The cases of widowers has been reported to be uniformly lower in various regions of the world [2]. Indeed the available reports indicate that the proportion of widowers is about 2-3\% among adult men in most regions. Accordingly, the ratio of widows to widowers is as high as 4 to 1 in most regions. This relation has been attributed to the age of men at marriage, shorter life expectancy and higher rates of remarriage. Studies have consistently reported that the loss of a spouse precipitates disruption of the family and related instability. The disruption that arises from the death of a spouse is accompanied by a wide range of changeswhich include change in income levels, property ownership, decision making, social interaction among others. This paper examines how the loss of a spouse affects social integration and decision making and the resultant effects of widows participating in selfhelp groups.

The widows are faced with the challenge of social integration and decision making with regard to family matters. Marris [9] conducted a study on widowed women in East London that centered on their grief and social conditions. He found that widows had a difficult time coping with their grief while adjusting to their new state [9, p.10]. This had a bearing on how the widows' relationship with other people progressed. The social relationships of these widows were affected because they had little time to socialize as they had to go to work and to perform household duties. In some instances widows are considered a threat to other married women and thus widows are left isolated to socialize amongst themselves [10,11].This implies that widows are often forgotten as they symbolize an unhappy episode in society. The needs of these widows have not disappeared with the death of their husbands. Like other human beings, they still have the need to socialize with other members of society.

Amongst the Nandi of Kenya, this is contrary, Oboler [12] found out that widows frequent beer halls and become involved in debates with men. Some widows do enjoy greater social activity due to increased freedom [11]. However, they do not hold any decision-making capacity on behalf of the community as is usually, the case for women in most patrilineal societies. Amongst the Taita of Kenya, Nelly [6] established that widows are socially active in the church women groups. They even take up leadership positions depending on one's strengths. However, according to the study, widows reported that they did notfeel free to mix with others because of suspicion that they were out to steal other womens' husbands. Some widows also cited lack of love from neighbours as one main cause that prevented them from visiting and socializing. Widows mostly visited relatives, friends and the sick. It is evident that in most instances the social networks decreases. Various studies have indicated that the consequences of losing a spouse are substantially different for men and women. These studies show that in most societies, widowers have greater freedom to remarry than their female counterpart. In addition, they have more extensive property rights, wider opportunities and more authoritative claim on economic support from his children [13-15].The restrictions widows face place them in high dependence on others for economic support. The extent and nature of 
family and community support becomes very critical to their well-being and the well-being of their children. Despite social ideals of support and protection, widows in many regions of the world are the most economically, socially and physically vulnerable group within given populations $[2,16,11,6]$.

In Rwanda, the genocide of 1994 left the country devastated.Around one million people were killed creating home to many widows. The self-help approach was introduced in the year 2006. The concept has taken root in some communities, for example, the self-help members of Gikumbi district have taken up wheat cultivation as a group activity. To them, wheat growing is the most profitable crop that increases their income and reduces poverty levels. The proceeds have enabled them to buy land, take care of their children and send them to school. In Zwaziland, the economy is dominated by agriculture and subsistence farming. Growth has been hampered by the effects of HIV/AIDS, the prevalence which is almost the highest in the world. The self-help approach was introduced in 2004. The members plant maize and vegetables and have started various small enterprises to improve family income. Some women gather special grass to make brooms, this has proved a lucrative business for local women. These groups' activities are planned and carried out by the members. Meetings are held once a week and decisions made and agreed by the members. (http://www.self-help.com/caseStudies.aspx).

In Kenya, self help groups are numerous. The self help group's community devotes their efforts to accessing information, learning new technologies and pooling resources to acquire inputs or to market their surplus. Part of the need for grassroots rural organizations in Kenya is related to the collapse of formal extensions and services to the small hold agricultural sector. A few years ago, several programmes were initiated in maize marketing, fertilizer supply and veterinary medicine. In the recent past, these services became scattered and virtuorly non existent. More than 200 sand dams have been built, serving as reservoirs for millions of litres of rain - harvested water. More than 8, 500 domestic water tanks have been constructed. They are also involved in brick making, have a housing scheme at Kola Town where they have constructed rental houses for civil servants and other tenants [17].

In Nandi county, there are over one thousand self help registered groups (Ministry of Gender, Children and Social Development Kapsabet). These groups are between 15 - 20 members. They meet once a week to discuss various issues with regard to their groups. They have a variety of activities such as poultry keeping, fish farming, tree nurseries for seedling establishment, bee keeping among others. The proceeds from these activities are invested or at times depending on the needs of the members are shared.

\section{METHODOLOGY}

The study was carried out in Nandi Central District part of the wider Nandi County. The study targeted a sample size of two hundred and fifty widows, the sample was proportionately distributed across twenty locations in the district. Data was collected using a structured questionnaire with both open and closed ended questions.Case histories was also used where key informants were interviewed and two focussed groups discussions conducted.

The paper is grounded on Social Exchange Theory, The Social Network and the Theory of Redefinition by William Thomas. The Social Exchange Theory explains the interaction of at least two individuals. Its main theme is about social interaction and exchange of rewards/costs. The social exchange theory has four building blocks: the actors, resources, structures and processes. The actors are the participants. They are purposive, that is, they have ends or goals toward which their actions are aimed. In the study, the actors are the widows and they aim at using the resources from the self-help group among others to enhance their 
socioeconomic status. The resources refer to the benefits / rewards of the group to the participants. Social exchange theory is about exchanging rewards. The people form associations / groups due to the rewards they expect. This serves to initiate, maintain and enhance the social bonds among the members according to Blau [21]. In a self help group,once ties are forged, the rewards that they provide to each other serve to maintain and enhance the bonds. The opposite is also possible, with insufficient rewards, an association can weaken or break. In this group, there is social interaction and the widows benefit from it.They are able to share the benefits /rewards. There is also a feeling of acceptance. Blau also says that people are attracted to a group when they feel relationship offer more rewards[21].

The Social Network Theory views social relationships in terms of nodes and ties . Nodes are the individual actors within the network and ties are the relationship between the actors. The theory studies regularities in how people behave, they are concerned with social relationships or the pattern of ties linking them. There is a network of social relations among the actors (widows). They have common interests and similar concerns. In the group, the widows are able to share, encourage and listen to each other. This network of social relations enhances cohesion, a feeling of identification with the group, the feeling that individual interests are bound up with the group.The functions of social network to an individual can be summarized as follows; a source of identity, a source of resources such as finances, source of information, psychological and social support among others. Thus, through participation in groups the individual benefits in various ways[21].

Theory of Redefinition (Definition of Situation) shows how the widows have had to redefine their situation upon the loss of the spouse. This theory is attributed to William Thomas and Znanie' Ki in the 1920's. They came up with the theory of cognition. They posit that human beings start with the way they are and when they find that they are not comfortable , they change their cognition, their attitude and finally their behaviour. These decisions have to do with redifining their situation. According to William Thomas, people usually redefine their situation when there is a crisis. It means that what has been defined for you by society and culture is not working, it leads to new ways of thinking and acting. This applies to the widows , when one loses a spouse, it is a crisis, th.ere is disruption of family life.The widow looks for alternative ways of coping with the situation, such as joining the groups. The three theories therefore have a convergence point and they complement each other.

The main objective was to examine the influence of selfhelp groups on the socioeconomic status of the widows. The paper thus examines the circumstances under which the widows lived before and after the loss of their spouses with regard to social integration and decision making. It will then discuss how the selfhelp groupshave helped the widows to be integrated into the community and also in making decisions that affect their families.

In order to achieve this, the study looked at the level of participation before the loss of the spouse, after the loss of the spouse and how the groups have made an impact on the level of social integration. The study related the frequency of meetings in self help groups and percentage in the improvement or deterioration in social integration. In the operationalization of variables, social participation is measured by the visits from the family, relatives, the church and whether the visits increased or deccreased upon the loss of the spouse. The participation in selfhelp groups is measured by the freguency of meetings, once a week, twice a month and once a month. The paper restricts itself to two areas namely; Social Integration and Decision Making. 


\section{FINDINGS AND DISCUSSION}

As discussed earlier, this paper examines the challenges widows faced with regard to social integration, the indicators here were the visits made to the widow by the family, relatives, friends and the church. In order to establish the level of social integration, the study looked at the visits before and after the loss of the spouseand how the selfhelp groups have bridged the gap.

\section{Challenges faced by widows with regard to social integration}

Table 1. Participation in Self Help Groups and Social Integration in the Community

\begin{tabular}{|l|l|l|l|l|l|l|l|l|l|l|l|l|}
\hline & \multicolumn{3}{|c|}{ Percent Deteriorated } & \multicolumn{6}{l|}{ Percent Improved } \\
\hline & & $\mathbf{0 - 2 0}$ & $\mathbf{2 1 - 4 0}$ & $\mathbf{4 1 - 6 0}$ & $\mathbf{6 1 - 8 0}$ & $\mathbf{8 1 - 1 0 0}$ & $\mathbf{0 - 2 0}$ & $\mathbf{2 1 - 4 0}$ & $\mathbf{4 1 - 6 0}$ & $\mathbf{6 1 - 8 0}$ & $\begin{array}{l}\mathbf{8 1}- \\
\mathbf{1 0 0}\end{array}$ \\
\hline $\begin{array}{l}\text { Once a } \\
\text { week }\end{array}$ & $\mathrm{N}$ & 12 & 11 & 31 & 17 & 1 & 23 & 14 & 19 & 13 & 6 \\
\hline & $\%$ & 16.7 & 15.3 & 43.1 & 23.6 & 1.4 & 30.7 & 18.7 & 25.3 & 17.3 & 8 \\
\hline $\begin{array}{l}\text { Twice a } \\
\text { month }\end{array}$ & $\mathrm{N}$ & 4 & 13 & 14 & 6 & 3 & 16 & 7 & 4 & 10 & 3 \\
\hline & $\%$ & 10 & 32.5 & 35 & 15 & 7.5 & 40 & 17.5 & 10 & 25 & 7.5 \\
\hline $\begin{array}{l}\text { Once a } \\
\text { month }\end{array}$ & $\mathrm{N}$ & 11 & 11 & 22 & 13 & 0 & 20 & 11 & 19 & 12 & 4 \\
\hline & $\%$ & 19.3 & 19.3 & 38.6 & 22.8 & 0 & 30.3 & 16.7 & 28.8 & 18.2 & 6.1 \\
\hline Total & $\mathrm{N}$ & 27 & 35 & 67 & 36 & 4 & 59 & 32 & 42 & 35 & 13 \\
\hline & $\%$ & 16 & 20.7 & 39.6 & 21.3 & 2.4 & 32.6 & 17.7 & 23.2 & 19.3 & 7.2 \\
\hline
\end{tabular}

Table 1. shows that the widows who participated in the self help groups were socially integrated. For the respondents in the category of $81-100 \%$ their level of integration improved by $8 \%$, the widows who met twice a week reported an improvement of $20 \%$ in their integration as opposed to $10 \%$ deterioration. On the other hand, those who met once a month also improved though not substantially as compared to the other two categories. On the category of $41-60 \%$, the social integration improved by $28.8 \%$ but deteriorated by $22.8 \%$. It was established by the authors that the respondents who met once a month were mainly on formal employment. Some were teachers, nurses, clerks hence engaged throughout the week.On the contrary, those who met once a week and twice a month were mainly selfemployed and the farmers (small scale) and were flexible interms of time management hence attended the group meetings regularly.It was established that group attendance provided an opportunity for them to network and to share the challenges.One widow had this to say; "I look forward to attending the group every week, it helps me to share the challenges, I feel relieved after sharing" (41 year old widow). It was a time of offering support to one another, a social network where they would encourage and sharpen each other. This is in line with social network theory. It was noted that the widows who had just joined the groups were still adjustinghence did not feel much integrated as compared to those who had stayed in the group for long. Generally, it was established that the groups helped the widows to feel integrated after the loss of their spouses. The information gathered from the field shows that before the loss of the spouse, there were visits from the family and they felt part of the family but when they lost their spouses the family visits decreased and the widows became lonely and isolated. After they joined the self help groups they felt a sense of belonging. The following information captureswhat the widows were going through. 
Table 2. Previous Level of Interactions( Before the loss of the spouse)

\begin{tabular}{|l|l|l|l|l|l|l|}
\hline & & Daily & Weekly & Monthly & Quarterly & Yearly \\
\hline Family & $\mathrm{n}$ & 174 & 34 & 19 & 6 & 7 \\
\hline Relatives & $\%$ & 72.5 & 14.2 & 7.9 & 2.5 & 2.9 \\
\hline & $\mathrm{n}$ & 17 & 92 & 83 & 28 & 20 \\
\hline Friends & $\%$ & 7.1 & 38.3 & 34.6 & 11.7 & 8.3 \\
\hline & $\mathrm{n}$ & 116 & 90 & 32 & 2 & 0 \\
\hline Church members & $\%$ & 48.3 & 37.5 & 13.3 & 0.8 & 0 \\
\hline & $\mathrm{n}$ & 19 & 216 & 5 & 0 & 0 \\
\hline & $\%$ & 7.9 & 90 & 2.1 & 0 & 0 \\
\hline
\end{tabular}

Theauthors point out how frequently family, relatives, friends and church members used to visit the respondents before the death of the spouse. The findings indicate that $72.5 \%$ (174) reported that family members used to visit them daily, while $14.2 \%$ (34) visited weekly and only $7.9 \%$ (19)paid a monthly visit. Regarding the relatives' visits $38.3 \%$ (92) paid a weekly visit, while $34.6 \%(83)$ paid monthly visits and only $11.7 \%$ (28) paid quarterly visits. Further, the respondents reported that $48.3 \%$ (116) of the friends paid daily visits, $37.5 \%$ (90) paid weekly visits and none paid yearly visits. Finally, the study findings showed that majority $90 \%$ (216) of the church members' paid weekly visits, while $7.9 \%$ (19) paid daily visits and none paid neither quarterly nor yearly visits. However,the table below shows that there is a decrease in the level of integration.

Table 3. Present Levels of Interaction (After the loss of the spouse) $\mathbf{N}=\mathbf{2 4 0}$

\begin{tabular}{|l|l|l|l|l|l|l|}
\hline & & Daily & Weekly & Monthly & Quarterly & Yearly \\
\hline Family & $\mathrm{N}$ & 113 & 48 & 38 & 10 & 27 \\
\hline & $\%$ & 47.9 & 20.3 & 16.1 & 4.2 & 11.4 \\
\hline Relatives & $\mathrm{N}$ & 19 & 43 & 84 & 38 & 47 \\
\hline Friends & $\%$ & 8.2 & 18.6 & 36.4 & 16.5 & 20.3 \\
\hline & $\mathrm{N}$ & 89 & 79 & 50 & 9 & 10 \\
\hline Church members & $\%$ & 37.6 & 33.3 & 21.1 & 3.8 & 4.2 \\
\hline & $\mathrm{N}$ & 29 & 195 & 9 & 2 & 2 \\
\hline & $\%$ & 12.2 & 82.3 & 3.8 & 0.8 & 0.8 \\
\hline
\end{tabular}

The study findings indicated that $47.9 \%$ (113) of the widows were paid daily visits by the family members, while $20.3 \%$ (48) were paid weekly visits and only $16.1 \%$ (38) were paid a monthly visit. This implies that the levels of interraction from the family members changed. Secondly, majority $36.4 \%$ (84) of the widows were paid monthly visits by the relatives while $20.3 \%$ (47) were paid yearly visits; this suggests that relatives change their interaction status after the death of the spouse.The findings also show that $37.6 \%$ (89) of the widows were visited by friends daily while $33.3 \%$ (79) were visited weekly, this implies that friends have the highest levels of interaction. Finally, $82.3 \%$ (195) of the widows were visited by the church members weekly .The findings on previous and present levels of interraction show that when the spouse was alive the family visits were frequent, upon the loss of the husband they decreased substantially as comparably shown on tables 2 and 3 . The authors confirmed this with the case histories where widows narrated how the families have not been visiting them the way they used to before the loss of their spouses. One widow narrated how her sister in law stood during the funeral and gave a speech that shocked the widow. The following are the words uttered by the sister-in-law; "Our brother has gone and we have nothing left! On the part of friends the visits decreased. The married family friends reduced their visits. The young 
widows were mainly affected due to the fact that the wives of the friends feared that the widows could snatch their husbands. It was also attributed to the fact that they did not have much in common especially with the man. Initially they would go out to socialize together as family friends and would discuss similar issues touching on the marriage, children and investment. With the loss of the husband things changed. The other reason cited is that of assistance especially financial. The level of interaction is affected. The widows cited loneliness and isolation. This is in line with what Nelly [6], Owen [10], Morgan [18] observed in their studies, where the widows were left to socialize on their own for they are considered a burden and a threat to other married women. The group between $26-40$ years (54\%) is a group of young widows and their challenges are quite unique as compared to other groups. One widow shared how she used to have so many married friends before she lost her spouse and since then they have all disappeared and her friendsnow are the widows and her children, for she identifies with them. It was also observed that they have many responsibilities and hardly have time to go out and socialize with others. One widow who is a teacher shared how she does not have time to go out and socialize and she had this to

During the week I am busy in school, over the weekend I check on the shamba to see what the workers have been doing. I also need to spend time with the children because I am the father and the mother (36year old widow kaplamai location).

It was gathered that they hardly have time. The work initially done by the husband is now hers. This is in line with the study conducted by Marris [9]. He found out that the widows had a difficult time coping with grief while adjusting to their new state. Their social relationships were affected because they had little time to socialize as they had to go to work and perform household duties as well.It was also observed that this young group of widows get into relationships with men, get more children and this becomes a burden. This has consequences as it causes stigma and lack of respect from the family. In other instances it is accepted, especially in instances where the widow was left with few children and of one sex. The widows were quick to point out that one should be self-disciplined and not to have many children because of the needs. From the widows interviewed, many emphasized the importance of selfrespect. The church played a role in integrating the widows into the community. They preached hope. They organized harambees for the children school fees, medical fees among others. Although the widows felt that the support is not sufficient,they were quick to point out that the church is trying to assist them. The church also organizes forums where they are talked to on issues that affect them such as health, children especially during the women's meetings. The authors note that as much as they did not feel integrated, they were taught well on the word of God and this gives them strength.

From what was gathered in the study, the church is a force to reckon with in influencing the lives of the widows. Majority of the widows felt that the church needs to empower them more. From the foregoing discussion, one can say that both the visits to the widow and the preaching is important in the lives of the widows.They bothencourage the widows and feel part and parcel of the community. In conclusion, the church integrates the widows more and this explains the fact that the majority of the widows attend church.

Table 4 below illustrates the difference between the church and the others in terms of visits and its ratings. 
Table 4. Rating on the Visits for family, relatives, friends and church members

\begin{tabular}{|l|l|l|l|l|}
\hline & \multicolumn{3}{|l|}{ Percent increase (0-100\%) } & \multicolumn{2}{l|}{ Percent Decrease (0-100\%) } \\
\hline & Mean & Std. Dev & Mean & Std. Dev \\
\hline Family & 13.48 & 24.515 & 32.33 & 29.823 \\
\hline Relatives & 11.38 & 21.193 & 36.03 & 29.735 \\
\hline Friends & 16.13 & 23.944 & 19.13 & 22.788 \\
\hline Church Members & 24.57 & 25.638 & 7.42 & 17.968 \\
\hline
\end{tabular}

The study findings indicate that church members increased visits by $24.57 \%$ in the widowhood status, while friends increased visits by $16.13 \%$ and relatives increased visits by $11.38 \%$. In addition, relatives decreased their visits by $36.03 \%$, followed by family members by $32.33 \%$, and church members decreased visits by $17.96 \%$. This suggests that church members are more involved in consoling the widows. This is also in line with the Biblical principles where the church of Christ has an obligation to take care of the widows and the orphans.

\section{Self Help Groups and Communal Activities}

It is important to note that the self help groups played a key role in organizing communal activities. This helped the widows to interract through participating in various other and they became not only empowered but were but were able to interact with others outside the family. It was established that some of these activities include; Initiation and wedding ceremonies, visits to members, trainings and workshops, community meetings such as barazas among others.The members noted that the groups have played a key role in enhancing their self-esteem. The group exposed them to various forums and this has compensated the reduced visits from the family, relatives and friends. In these activities they have made new friends and have learnt a lot from them. The groups organize for the members to meet with other groups, in the course of these visits, they learn new things and have an opportunity to interact with others. One particular group from chemundu learn a lot from Lolminingai,this said group has established a poultry project, where they sell chicks, eggs and chicken. They share the profits among the members. During the market day at chepterit trading centre the members sell boiled eggs with "kachumbari". They are paid a commission and the profit goes to the group which is then used to give loans to the members. Indeed, the groups have played a key role in ensuring that the widows are not lonely but they are socially integrated into the community

\section{The Influence of Selfhelp Groups on the Decision Making among the Widows}

In this section, the paper looks at the decisions made by the spouse while alive, the decisions the widows can make and those they are not allowed to make. It will also examine how the selfhelp groups have influenced the decision making by the widows through their participation in trainings. 
Birech, J., \& Masinde, J. (2018). The Influence of Selfhelp Groups in Enhancing Social Integration and Decision Making among the Widows in Kenya. Advances in Social Sciences Research Journal, 5(5) 52-66.

Table 6. Relationship between Participation in Self Help Groups and Decision Making in the Family

\begin{tabular}{|l|l|l|l|l|l|l|l|l|l|}
\hline & & \multicolumn{4}{|l|}{ Percent deteriorated } & \multicolumn{4}{l|}{ Percent Increased } \\
\hline & & $0-20$ & $21-40$ & $41-60$ & $61-80$ & $0-20$ & $21-40$ & $41-60$ & $61-80$ \\
\hline Once a week & $\mathrm{n}$ & 41 & 5 & 4 & 5 & 29 & 17 & 11 & 11 \\
\hline & $\%$ & 74.5 & 9.1 & 7.3 & 9.1 & 42.6 & 25 & 16.2 & 16.2 \\
\hline Twice a month & $\mathrm{n}$ & 23 & 2 & 2 & 6 & 14 & 12 & 7 & 3 \\
\hline & $\%$ & 69.7 & 6.1 & 6.1 & 18 & 38.9 & 33.3 & 19.4 & 8.3 \\
\hline Once a month & $\mathrm{n}$ & 32 & 2 & 14 & 5 & 27 & 14 & 16 & 2 \\
\hline & $\%$ & 60.4 & 3.8 & 26.4 & 9 & 45.7 & 23.8 & 27.1 & 3.3 \\
\hline Total & $\mathrm{n}$ & 96 & 9 & 20 & 16 & 70 & 43 & 34 & 16 \\
\hline & $\%$ & 68.1 & 6.4 & 14.2 & 11.3 & 42.9 & 26.4 & 20.9 & 9.8 \\
\hline
\end{tabular}

From the above cross tabulations, the pattern shows that there was an improvement in decision making as compared to those whose decision making deteoriorated.For the widows who attended the meetings once a week on the category of $0-20 \%, 42 \%$ of the respondents said their decision making ability increased as compared to $74.5 \%$ whose rate in decision making deteriorated. As mentioned earlier, the majority of the widows in this category were self employed and practised small scale farming, they attained primary level of education. The authors established that they were adversely advected upon the loss of their spouses, due to limited decision making skills. Their participation in groups therefore empowered them to make family decisions. The frequency of meetings, trainings organized by the groups, allocation of duties such as leadership roles, facilitated their acquisition of decision making skillsOn the category of those who attended meetings twice a month and once a month consecutively, there was also an increase in decision making. The widows in the $61-80 \%$ category reported $8.3 \%$ and $16.6 \%$ increase as compared to 9 and $18 \%$ decrease. The majority of the widows who attended once a month were in formal employment. It was established that some were already in leadership positions, some were given leadership positions in the groups. Their participation in groups therefore stenghened their decision making skills. From the foregoing discussion, the paper concludes that the level of education coupled with group participation played a role in empowering the widows to make decisions. This was captured from the following informationwhich showed the status of widows interms of making decisions before and after the loss of the spouse and the gains from the group.Table 6 shows the decisions which were previously made by the spouse.

Table 7. Previous Decisions Made by the Spouse ( $\mathrm{N}=226)$

\begin{tabular}{|l|l|l|}
\hline Role of the spouse & Frequency & Percent \\
\hline Farming & 90 & 39.8 \\
\hline Education & 138 & 61.1 \\
\hline Selling land/ property & 39 & 17.3 \\
\hline Bridewealth negotiation & 2 & 0.9 \\
\hline Budgeting/ Income and expenditure & 75 & 33.2 \\
\hline Development/Family issues & 124 & 54.9 \\
\hline Business & 31 & 13.7 \\
\hline Inheritance & 1 & 0.4 \\
\hline
\end{tabular}

According to the study findings majority $61.1 \%$ (138) reported that their spouses made decisions regarding education, followed by $54.9 \%$ (124) who were involved on family issues/development, while 39.8\% (90) made farming decisions and 17.3\%(39)made decision 
on selling land/property. As mentioned the district is predominantly Nandi in ethnic composition and is a patriarchal community wherebythe men head their families, they make major decisions and women are restricted to domestic duties. The men make major decisions with regard to development, when to sell or buy property, the payment of bridewealth, where to farm and buy farm inputs and the education of the children.

This paper establishes that men are the main decision makers and women make complementary decisions such as what to cook, what to eat, planting of vegetables and taking careof children. This concurs with the study done by Oboler [12], which says that Nandi Women have freedom to frequent beer halls upon the loss of their spouses but they do not make decisions. This implies that there will be some element of stagnation in the family, there is a likelihood that the projects started by the spouse will not be continued. It is important to point out that those economically empowered were able to make decisions easily as compared to those who were not.Also, the authors identify the present decisions made by the widows as shown in table 8.

Table 8. Present Decisions Widows ( $\mathrm{N}=232)$

\begin{tabular}{|l|l|l|}
\hline Decisions made by the widow & Frequency & Percent \\
\hline Farming & 107 & 46.1 \\
\hline Education & 139 & 59.9 \\
\hline Selling land/ property & 6 & 2.6 \\
\hline Bridewealth & 1 & 0.4 \\
\hline Budgeting/ Income and expenditure & 57 & 24.6 \\
\hline Development/Family issues & 110 & 47.4 \\
\hline Business & 33 & 14.2 \\
\hline
\end{tabular}

Based on the study findings majority 59.9\%(139) of the respondents make decisions regarding education, followed by $47.4 \%$ (110) who decides on family issues/development. It was important to note that $46.1 \%$ (107) are involved in farming decision making and only $24.6 \%$ (57) are involved in budgeting/income and expenditure decision making. This implies widows' takes over most of the decisions made by their husbandsUpon the loss of the spouse the woman found herself in a dilemma and unable to make certain decisions on her own because she was not allowed to make such decisions due to the cultural orientation. In such cases she had to consult the extended family members . The findings are presented in Table 9.

Table9. Decisions Made with Consultations ( $\mathrm{N}=171)$

\begin{tabular}{|l|l|l|}
\hline Decisions made by the widow with consultations & Frequency & Percent \\
\hline Boys Circumcision & 70 & 40.9 \\
\hline Selling land/ property & 88 & 51.5 \\
\hline Remarriage & 40 & 23.4 \\
\hline Dowry/Children marriage & 24 & 14 \\
\hline Farming & 2 & 1.2 \\
\hline Closing/Expanding business & 7 & 4.1 \\
\hline Family welfare/disputes & 28 & 16.4 \\
\hline
\end{tabular}

The findings indicate that majority $51.5 \%$ (88) of the respondents do not make decisions such as selling of the property /land, as compared to $40.9 \%(70)$ decided on boy's circumcision with consultation. It was important to note that $16.4 \%$ consulted on decision regarding family welfare/disputes, while $23.4 \%$ (40) and 14\% (24) cannot decide on remarriage and dowry/children marriage respectively. In addition, the study found out the reasons why the 
spouse did not make some decisions on their own include family approval, taboo and culture and the fact that men made major decisions.

The study findings showed that majority $62.6 \%$ do not make decisions on their own since they have to get family approval or are not allowed, while $23.4 \%$ fails to make decisions because of taboos while the role played by men is 5.3\% Therefore, it can be implied that families are pillars in widows decision making.This kind of set up limits the widow in terms of decision making, it also puts the widow at the mercy of the family and open to manipulation. The family members especially the brothers in-law of the widow take advantage and they ask the widow for favours if they are to be allowed to make some decisions. Further, the study sought to establish some activities in which self help groups have helped in decision making, only 167 widows responded to the question as shown in Table 11.

Table11. Group Activities that Helps in Decision Making ( $\mathrm{N}=167)$

\begin{tabular}{|l|l|l|}
\hline Group Activities and decision making & Fequency & Percent \\
\hline Seminars/training forums & 55 & 32.9 \\
\hline Participation in community activity & 8 & 4.8 \\
\hline Guidance and counseling & 22 & 13.2 \\
\hline Finance education/services & 12 & 7.2 \\
\hline Group discussion & 46 & 27.5 \\
\hline Leadership role in the group & 17 & 10.2 \\
\hline Family cohesion & 1 & 0.6 \\
\hline Economic/social empowerment & 36 & 21.6 \\
\hline
\end{tabular}

The study findings indicated that $32.9 \%$ (55) of the respondents participated in seminars and training forums organized by the self help groups, $27.5 \%(46)$ participated in group discussions during their meetings, $13.2 \%$ (22) participated in guidance and counseling sessions. Therefore, participation in group activities can help to alleviate problems associated with decision making. It was gathered that the group organizes activities that assist the widow in making decisions. One widow who is 60 years old narrated that she decides on some major issues such as the engagement of her children and then informs the family. It was also observed that this widow is economically stable and runs a business. One widow, a high school teacher makes decisions on her own.She can decide to take a loan and buy a piece of land as long as there are valid documents and owner is willing to sell.

It was observed that education and economic status play a role in decision making. The poor and young widows were quite helplessness in terms of decisions making. The groups have come in to assist them. In general, the widows agreed that the groups have played a role, however they pointed out that there are still decisions, that have to be consulted upon, gathered from the field is that the widows valued familyunity and peace. They would not want to engage in any activity that would bring disunity among the family members.

The authors observed that the widows obtained skills which helped them to to guide and even to counsel their children. They learned leadership skills which became critical in managing their families. The training and exposure helped them to deal with their own issues such as self esteem, loss and grief among others. This helped them to not only understand themselves but also their children. 


\section{Self-Help Groups and Decision Making}

The findings showed that $68.1 \%$ of the respondents felt that they could make decisions on their own. Therefore, widows should be encouraged to participate in selfhelp groups soas to increase their roles in decision making process. From the foregoing discusion, the authors conclude that the selfhelp groups play a role in enhancing the decision making process of the widows. During the intervews, it was observed that the widows who were in groups exuded a feeling of confidence as compared to those who did not belong to any group. One widow who belonged to Tumaini group had this to say:"Since I joined the group, Iam able to decide what is beneficial to my family, able to face my brother in law and discuss with him what I want, but before that I used to fear" (40 years old widow).

This level of confidence is cultivated and instilled through participation in groups. Indeed, this concurs with the social exchange theory which brings out the aspect of cost and benefits in any relationship. The widows acquire decision making skills from the group through their participation.. It was noted that the spirit of reciprocity is strong, in the process they are empowered. Studies have shown that self help groups in India have empowered women in decision making and ascending to leadership positions. They banned the local sale and consumption of alcohol and chewing tobacco among the village men and youth, they organized several sit ins at the local liquor store to get it to close down [19].

In summary, the aspect of patriarchy was found to be relatively strong among the community, the widows were handicapped in decision making and this affected other aspects of their life.It was found out that the husband is the main decision maker; they made major decisions that affect the family such as development, investment, circumcision, dowry for the children and education matters. The wife makes minor decisions such as cooking and taking care of the children. This was a challenge that faced most of the widows. Without decisions, the family stagnates. However, this mainly affected young widows. The findings show that the older widows were relatively free in terms of decision making.The young widow faces unique challenges as compared to older widows. The young ones do not have freedom to make decisions. This implies that the community do not think they have capacity to make decisions that influence the family. It was also concluded that the old widows have a responsibility to mentor the young ones. The authors observed that the older widows are of different categories, there are those who were economically able and those who were not able. It was observed that those who were able commanded more respect than those who were not able. It was concluded therefore that economic empowerment cuts across all ages.

The level of interaction was affected. The widows cited loneliness and lack of support from the family, relatives and friends. Theauthors concludes by saying that, awareness should be created on the importance of integrating the widow into the community. The families, relatives and friends should be made to understand that the widows need emotional, economic, spiritual and social support. The church should also play a great role in interacting and integrating them. They should be given leadership positions in the church such as women fellowship groups, organize forums where widows interact with each other. This builds a strong support system. This awareness can be done through the church, the barazas, and media among others. It was observed that the widows who participated in groups felt more integrated and equipped to make decisions.

\section{CONCLUSION}

The participation of widows in the self help groups have impacted greatly on their socioeconomic status. The groups help the widows to interact with the community members through various activities such as visits to members and non-members. They take part in 
various communal activities and they felt integrated. In addition, they were empowered to make decisions through trainings organized by the groups. . The findings show that the widows who participate in groups are able to stand and address a crowd. They are also able to make decisions on their own. The findings also show that there are still decisions that the widows consult. This is in line with the culture of the community. In general, the groups have a great influence in social integration and decision making among the widows.

\section{RECOMMENDATIONS}

Based on the findings, the paper recommends the following;

1. The widows who did not belong to any group missed out on opportunities that would have helped them raise income, make family decisions on their own and participate actively in the community. They should be encouraged to join the groups.

2. The study found out that some spouses died due to HIV/AIDS virus. Those whose husbands died of the virus face a lot of stigma. The family is hostile to them. They are unwell and they need support and medication.

3. The existing groups need to be strengthened by equipping them with leadership skills and introducing variety of activities that are income generating..

4. Finally, the Kenyan Government should come up with a clear policy on widows as a vulnerable group. The policy on the Older Persons Cash Transfer-OPCT and the Cash Tranfer to Persons with Disabilities CT-PWD which takes care of the aged and the disabled leaves out an important category of widows, the young and the vulnerable, those who have no source of income. It is evident from the study that widowhood is on the rise. For this reason, the Kenyan government, the civil society, the church should continue to create awareness on the subject, create more opportunities where the widows can sustain their livelihoods and emphasize on the importance of education. This requires a multisectoral approach.

\section{References}

Mathews, M. (1991). The relationship between support and morale: Comparisons of the widowed and never married in later life. Canadian Journal of Community, 10, 47-63.

Martha, C. (2000). Perpetual mourning: Widowhood in rural India.New Delhi: Oxford University Press.

Global Widow's Report (2015). A global overview of deprivation faced by widows and their children.

World's Women 2000, (2001). United Nations Publication on the Rights of Women.United Nations

Ambasa, S. (2004). Widowhood in the era of HIV/AIDS. A Study Carried Out in Siaya District: Kenya.

Nelly, M. (2004).The changes affecting widows in Taita Taveta.Unpublished Masters Thesis, University of Nairobi.

Ondieki, R. (2004). The challenges facing single mothers in Siaya District.Unpublished Masters Thesis, University of Nairobi.

World Bank, (2004). Gender and law. Africa Region Available, Findings No 126.

Marris, P. (1958).Widows and their families. Routledge and Kegan: London.

Owen, M. (1996).A world of widows. New Jersey:Zed Books

Lopata, H. Z. (1973). Widowhood in an American city. Schenkman Publishing Co.: Cambridge

Oboler, R.S. (1982). Women, men, property and change in Nandi District. A Ph D. dissertation submitted to the Temple University Graduate School.

Mbithi, P. (1974). Harambee self - help:the kenyan approach in rural sociology and rural development, Nairobi: Macmillian.

Ncube, W. (1989). Defending and protecting gender equality and the family under a decidedly undecided constitution in Zimbabwe. Zimbabwe Law Review 
Gray, L.,\&Kevane, M. (2000). Diminished access, diverted exclusion:Women and land tenure in Subsaharan Africa. African Studies Review 42 (September 2000)

Ntozi, J. (1997). Widowhood, remarriage and migration during the HIV/AIDS epidemic in Uganda. Department of Population Studies. Health Transition Review, 7(1), 125-144.

World Council of Churches, (2009). The role of the church in poverty alleviation.Council of Churches.

Morgan, L.A. (1986). The financial experience of widowed women. Evidence from Longitutinal Retirement History Survey. The Gerontologist, 26(6), 663-668. doi:10.1093/geront/26.6.663

IFAD, (2001).The impact of new credit and savings opportunities for women. Rome: Italy.

Mizruchi, M. (1991). Urgency, Motivation, and Group dynamics. Social Psychology Quartely, 1991, 54. $184-189$.

Ritzer, G. (2008). Sociological Theory. McGraw Hill: New York

Granovetter, M. (1983). The Strenght of Weak Ties. A Network Theory Revisited:Sociological Theory 1; 201-233.

\section{Internet sources}

(http://www.ifad.org/gender/learning/project/part/asia_empower.htm)

\section{Print sources}

Daily Nation Newspaper 26th April 2010 


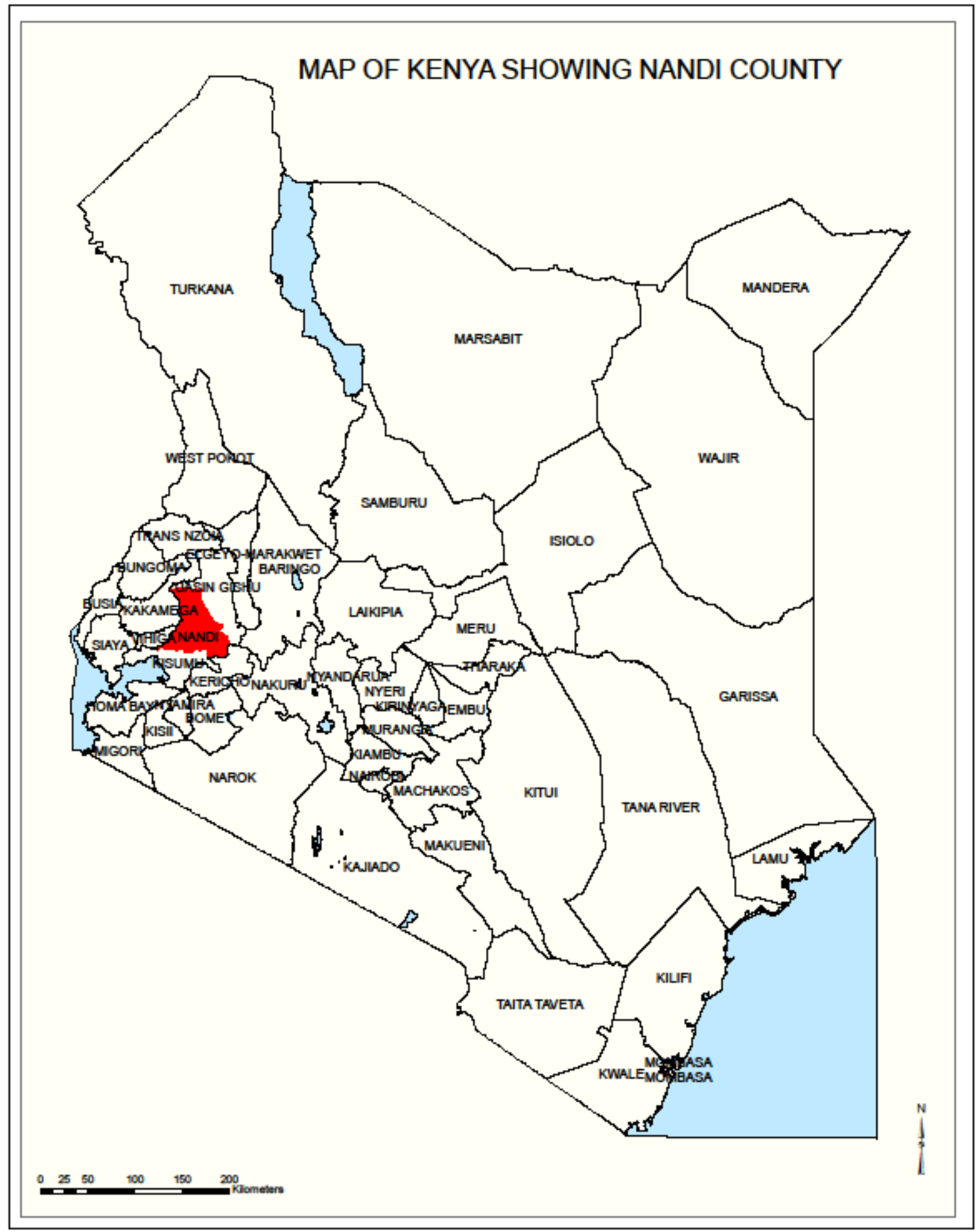

